\title{
GROWTH OF Spirulina platensis IN INDOOR AND SEMI OUTDOOR CULTURING SYSTEMS
}

\author{
Judita Grace Merry Nainggolan*, Afrizal Tanjung, Irwan Effendi \\ ${ }^{1}$ Faculty of Fishery and Marine Sciences, University of Riau, Indonesia. \\ * judita.nainggolan@gmail.com
}

\begin{abstract}
Microalgae are very potential to be developed as biofuel feedstocks when compared to food crops because they have several advantages such as rapid growth, high productivity, enabling the use of freshwater and seawater, and production costs are not too high. Spirulina platensis has a high nutrient content so it is used as a health food ingredient. Once the importance of the role of nutritional value of $\mathrm{S}$. platensis for humans and some marine organisms, then the right culture medium to get the maximum nutritional content needs to be studied more deeply. This study aims to determine the effect of different doses of nutrition on the density of biomass cultivation of S. platensis microalgae with indoor and semi outdoor system. This research has been conducted from April to May 2018. The method by used the experimental method. The data obtained were analyzed statistically using simple linear regression equation. The results showed that the influence in the dose of nutris media guillard, S.platensis increased with the dose of nutrients as much as $0.60 \mathrm{ml}$ either indoor or semi outdoor system. As for the amount of biomass density S. platensis in the semi-outdoor system the amount of biomass density is higher than the indoor system.
\end{abstract}

Key words: Microalga, Spirulina platensis, Sediment, Media Guillard

\section{PENDAHULUAN}

Mikroalga sangat potensial untuk dikembangkan sebagai bahan baku biofuel jika dibandingkan dengan tanaman pangan karena mempunyai beberapa keuntungan antara lain pertumbuhan yang cepat, produktivitas tinggi, memungkinkan penggunaan air tawar dan air laut, dan biaya produksi yang tidak terlalu tinggi. Menurut Amini et al., (2010), bahwa Mikroalga juga memiliki struktur sel yang sederhana, kemampuan fotosintesis yang tinggi, siklus hidup yang pendek, dapat mensintesis lemak, dapat bertahan pada kondisi lingkungan yang ekstrim serta tidak membutuhkan nutrisi yang banyak. Salah satu jenis mikroalga adalah Spirulina platensis.

Spirulina platensis memiliki kandungan nutrisi tinggi sehingga digunakan sebagai bahan makanan kesehatan. Spirulina mengandung 5 zat gizi utama, yaitu : karbohidrat, protein, lemak (gama linoleat, omega 3, 6, dan 9), vitamin (B-kompleks, $\mathrm{E})$, mineral $(\mathrm{Fe}, \mathrm{Ca}, \mathrm{K})$, serta pigmen alami (beta karoten, klorofil, xantofil, fikosianin). Oleh karena itu, spirulina dapat berfungsi sebagai antioksidan (mencegah kanker dan radikal bebas), meningkatkan sistem imunitas tubuh (daya tahan terhadap fluktuasi lingkungan dan serangan penyakit), serta merendahkan koesterol (Fikri, 2006). Media Guillard sering digunakan untuk budidaya Spirulina dan memiliki kandungan nutrisi yang lengkap. Media Guillard digunakan karena berdasarkan penelitian sebelumnya pada mikroalga Chaetoceros gracillis, media ini mendapatkan protein dan kadar lemak yang tinggi, kandungan $\mathrm{N}$ dan $\mathrm{P}$ media ini adalah $\mathrm{N}(\mathrm{NaNO} 3)=88,2032 \quad \mathrm{~g} / \mathrm{l}$, $\mathrm{P}(\mathrm{NaH} 2 \mathrm{PO} 4.2 \mathrm{H} 2 \mathrm{O})=10 \mathrm{~g} / \mathrm{l}$. Media ini biasa digunakan untuk kultivasi mikroalga 
dan diketahui dapat menghasilkan biomassa yang tinggi (Jati et al., 2012). Namun belum ada keterkaitan informasi dan penelitian mengenai pengaruh pemberian nutrisi dengan takaran yang berbeda pada kultur Spirulina platensis. Oleh karena itu, peneliti tertarik melakukan penelitian mengenai kerapatan biomassa Spirulina platensis dengan pemberian takaran nutrisi media guillard yang berbeda.

Tujuan penelitian ini untuk mengetahui pengaruh perbedaan dosis nutrisi Media Guillard atau F/2 terhadap jumlah kerapatan biomassa mikroalga $S$. platensis dalam Skala Indoor dan Semi Outdoor.

\section{METODE PENELITIAN}

Penelitian ini telah dilaksanakan dari bulan April - Mei 2018. Analisis kultur dan perhitungan kerapatan biomassa dilaksanakan di Laboratorium Biologi Laut, Fakultas Perikanan dan Kelautan Universitas Riau.

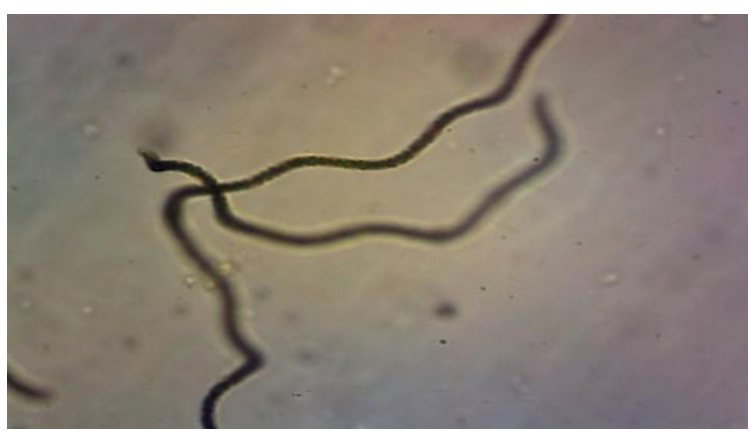

Gambar 1. Spirulina platensis

Rancangan percobaan yang digunakan dalam penelitian ini adalah Rancangan Acak Lengkap (RAL). Rancangan Acak Lengkap (RAL), Completely Randomized Design (CRD), merupakan suatu rancangan yang sangat sederhana bila dibandingkan dengan rancangan-rancangan baku lainnya. Rancangan ini berguna apabila unit-unit percobaan homogen (seragam), dimana variasi/keragaman dari unit-unit percobaan sangat kecil. Dengan demikian rancangan ini lebih cocok digunakan pada percobaan yang dilakukan dilaboratorium atau di rumah kaca karena menyangkut homogenitas dari unit-unit percobaan (Tanjung, 2014).

Metode yang digunakan dalam penelitian ini adalah metode eksperimen. Menurut Wiersma (1991) dalam Emzir (2009) mendefinisikan eksperimen sebagai suatu situasi penelitian yang sekurangkurangnya stu variabel bebas, yang disebut sebagai variabel eksperimental, sengaja dimanipulasi oleh peneliti.

Pada penelitian ini, bibit spirulina sebanyak $100 \mathrm{ml}$ yang didatangkan dari Surabaya dimasukkan ke dalam toples yang bervolume $3 \mathrm{~L}$, kemudian ditambahkan air laut sebanyak $1 \mathrm{~L}$, serta nutrisi yang terdiri dari vitamin dibutuhkan $0,25 \mathrm{ml} / \mathrm{L}$, trace element $0,5 \mathrm{ml} / \mathrm{L}, \quad \mathrm{NaHCO}_{3} \quad 0,5 \mathrm{ml} / \mathrm{L}$ $\mathrm{NaH}_{2} \mathrm{PO}_{4} \quad 0,5 \mathrm{ml} / \mathrm{L}$, Setelah semua tercampur, toples diberi aerasi dan dipasangkan lampu neon 40 watt untuk pencahayaan selama 24 jam setiap harinya. Kultur dilaksanakan selama 14 hari, dan diamati setiap harinya untuk melihat jumlah kerapatan.

Air laut yang sudah disediakan diatur salinitasnya dengan menggunakan handrefractometer menjadi 25\%, sesuai dengan hasil penelitian sebelumnya bahwa kadar salinitas biomassa S.platensis yang baik adalah 25\% (Sintya,2018). Kemudian air laut tersebut dimasukkan dalam 24 buah toples, skala indoor dan semi outdoor masing-masing menggunakan 12 buah toples. Setiap toples diisi dengan air laut sebanyak $500 \mathrm{ml}$.

Pada tahap ini disediakan terlebih dahulu gelas ukur dan tip yang sudah disterilisasikan, serta mikropipet. Kemudian disediakan larutan aquades, dan nutrisi yang terdiri dari vitamin, trace element, $\mathrm{NaHCO}_{3}, \mathrm{NaHPO}_{4}$. Setelah itu tuangkan 1 $\mathrm{ml}$ larutan aquades kedalam gelas ukur menggunakan mikropipet, kemudian masukkan kedalam larutan tersebut $0,25 \mathrm{ml}$ 
vitamin, $0,5 \mathrm{ml}$ trace element, $0,5 \mathrm{ml}$ $\mathrm{NaHCO}_{3}$, dan $0,5 \mathrm{ml} \mathrm{NaH} \mathrm{PO}_{4}$. Kemudian semua larutan tersebut diaduk agar tercampur secara merata. Larutan ini yang menjadi larutan nutrisi dan akan dimanipulasi takarannya menjadi $0,50 \mathrm{ml}$, $0,55 \mathrm{ml}$, dan $0,60 \mathrm{ml}$, dan dilakukan dengan 3 kali pengulangan dan 3 kontrol yang tidak diberi larutan nutrisi.

Selanjutnya diamati selama 14 hari, dengan penyamplingan dua hari sekali pada jam yang sama. Teknik penyamplingan digunakan untuk skala indoor dan semi outdoor, yaitu kultur spirulina diambil 50 $\mathrm{ml}$ dan dituangkan ke dalam gelas ukur, lalu difoto perubahan warna setiap proses penyamplingan, kemudian kultur disaring dengan menggunakan kertas saring yang berukuran sekitar 4-6 $\mu \mathrm{m}$ yang sudah dipersiapkan pada tahap preparasi dan sterilisasi, lalu kertas saring diletakkan pada vacum filter untuk menyaring kultur yang disampling tadi, setelah semua tersaring sempurna, kertas saring diangkat dari vacum filter menggunakan pinset dan dilipat menjadi 3 sisi dan dibungkus dengan kertas alumunium foil.

Kultur yang sudah disaring menggunakan vacum filter dan dibungkus menggunakan alumunium foil, dimasukkan ke dalam petridish yang telah diberi label terlebih dahulu, setelah itu kultur Spirulina platensis yang ada di dalam petridish dikeringkan dalam oven dengan suhu $105^{\circ} \mathrm{C}$ selama 5 jam. Setelah dioven selama 5 jam, petridish diambil dari oven.

Kemudian kertas saring yang dibungkus tersebut, dibuka dan dipisahkan dari bungkusannya, lalu ditimbang dengan menggunakan timbangan digital, dan dicatat beratnya. Maka berat biomassa kultur spirulina didapat dikurangi berat kertas saring saja, yang mana pada tahap preparasi dan sterilisasi kertas saring sudah ditimbang sebelumnya.
Perhitungan kultur stok Spirulina $\mathrm{sp}$. yang digunakan untuk kultur menggunakan rumus (BPPT,2013):

$$
\mathrm{PB}=\frac{\Delta \mathrm{W}(\mathrm{W} 0-\mathrm{W} 1)}{\mathrm{V}}
$$

Keterangan:

$\mathrm{PB}=$ Pertumbuhan Biomassa $(\mathrm{gr} / \mathrm{ml})$

$\mathrm{V}=$ Volume $(\mathrm{ml})$

$\mathrm{W}_{1}=$ Berat kertas saring + Berat kultur $(\mathrm{gr})$

$\mathrm{W}_{0}=$ Berat Kertas saring (gr)

Data yang diperoleh dari hasil perhitungan kerapatan biomassa Spirulina platensis disajikan dalam bentuk tabel dan grafik. Kemudian data tersebut dianalisis dan diuji dengan Analysis Of Variance (ANOVA) serta dibahas secara deskriptive yang mengacu pada literatur. Dan untuk mengetahui perbedaan pengaruh antara skala indoor dan semi outdoor dilakukan analisis menggunakan Uji T.

\section{HASIL DAN PEMBAHASAN}

\section{Parameter Kualitas Air.}

Pengukuran Kualitas Perairan dilakukan sebanyak 3 kali pengulangan dalam skala indoor dan semi outdoor. Untuk Rata-Rata Parameter Kualitas perairan dapat dilihat pada Tabel 3 untuk skala indoor dan Tabel 4 untuk skala outdoor.

Tabel 3. Parameter Kualitas Air pada Kultur Biomassa S.platensis dalam Skala Indoor.

\begin{tabular}{|c|l|c|c|c|c|}
\hline No & $\begin{array}{c}\text { Parameter } \\
\text { Kualitas Air }\end{array}$ & Kontrol & $\begin{array}{c}0,50 \\
\mathrm{ml}\end{array}$ & $\begin{array}{c}0,55 \\
\mathrm{ml}\end{array}$ & $\begin{array}{c}0,60 \\
\mathrm{ml}\end{array}$ \\
\hline 1 & Suhu $\left({ }^{\circ} \mathrm{C}\right)$ & 29,25 & 29,75 & 29,25 & 29,75 \\
\hline 2 & $\mathrm{pH}$ & 9,1 & 9,1 & 9 & 9 \\
\hline 3 & Salinitas (ppt) & 25 & 25 & 25 & 25 \\
\hline
\end{tabular}


Tabel 4. Parameter Kualitas Air Pada Kultur Biomassa S.platensis dalam Skala Semi Outdoor

\begin{tabular}{|c|l|c|c|c|c|}
\hline No & $\begin{array}{c}\text { Parameter } \\
\text { Kualitas Air }\end{array}$ & Kontrol & $\begin{array}{c}0,50 \\
\mathrm{ml}\end{array}$ & $\begin{array}{c}0,55 \\
\mathrm{ml}\end{array}$ & $\begin{array}{c}0,60 \\
\mathrm{ml}\end{array}$ \\
\hline 1 & Suhu $\left({ }^{\circ} \mathrm{C}\right)$ & 29,25 & 29,5 & 29,5 & 29,5 \\
\hline 2 & $\mathrm{pH}$ & 9 & 9,2 & 9,2 & 9,2 \\
\hline 3 & Salinitas (ppt) & 25 & 25 & 25 & 25 \\
\hline
\end{tabular}

Berdasarkan Tabel 3 dan Tabel 4 dapat dilihat bahwa hasil dari pengukuran parameter perairan menunjukkan kondisi perairan dalam keadaan tidak tercemar atau baik yaitu rata-rata suhu perairan dalam skala indoor berkisar $29,25-29,75^{\circ} \mathrm{C}$, dan $\mathrm{pH}$ berkisar 9-9,2. Sedangkan rata-rata suhu perairan dalam skala semi outdoor berkisar 29,25-29, $5^{\circ} \mathrm{C}$, dan $\mathrm{pH}$ berkisar 9-9,5. Pada skala indoor dan outdoor memiliki salinitas yang sama yaitu 25 ppt.

Dari pengukuran kualitas perairan yang didapatkan selama penelitian ini berlangsung, dihasilkan bahwa kualitas air yang digunakan dalam kondisi tidak tercemar. Sesuai dengan Isnansetyo et al., (1995) suhu untuk mikroalga berkisar 16$35^{\circ} \mathrm{C}$.

Salinitas yang optimal untuk pertumbuhan Spirulina adalah berkisar antara 15- 30 \%o (Hariyati, 2008). Nilai pH yang baik untuk S.platensis berkisar antara 8,5-9,5. Hal ini menunjukkan bahwa $\mathrm{pH}$ air yang didapat dalam skala indoor dan semi outdoor tergolong belum tercemar dan belum terganggu dari sekitarnya (Suryati, 2002).

\section{Pertumbuhan Biomassa S. platensis.}

Perhitungan kultur biomassa dilakukan untuk mengetahui tingkat kerapatan biomassa S.platensis yang dilakukan pada skala indoor dan semi outdoor sebanyak 3 kali pengulangan dalam satu skala. Hasil perhitungan kultur biomassa dapat dilihat pada Tabel 5 dan Tabel 6.

Tabel 5. Perhitungan Kultur Biomassa S.platensis dengan Pemberian Nutrisi yang berbeda dalam Skala Indoor.

\begin{tabular}{|c|c|c|}
\hline Nutrisi & $\begin{array}{c}\text { Hari } \\
\text { Penyamplingan }\end{array}$ & $\begin{array}{l}\text { Rata-Rata Kerapatan Biomassa } \\
(\mathrm{gr} / \mathrm{ml})\end{array}$ \\
\hline \multirow{8}{*}{0,00} & 0 & 0,126 \\
\hline & 2 & 0,342 \\
\hline & 4 & 0,436 \\
\hline & 6 & 0,510 \\
\hline & 8 & 0,731 \\
\hline & 10 & 1,191 \\
\hline & 12 & 1,426 \\
\hline & 14 & 0,551 \\
\hline \multirow{8}{*}{0,50} & 0 & 0,264 \\
\hline & 2 & 0,534 \\
\hline & 4 & 0,729 \\
\hline & 6 & 0,748 \\
\hline & 8 & 0,918 \\
\hline & 10 & 1,556 \\
\hline & 12 & 1,667 \\
\hline & 14 & 0,757 \\
\hline \multirow{8}{*}{0,55} & 0 & 0,378 \\
\hline & 2 & 0,756 \\
\hline & 4 & 0,848 \\
\hline & 6 & 1,240 \\
\hline & 8 & 1,317 \\
\hline & 10 & 1,656 \\
\hline & 12 & 1,741 \\
\hline & 14 & 0,839 \\
\hline \multirow{8}{*}{0,60} & 0 & 0,623 \\
\hline & 2 & 0,956 \\
\hline & 4 & 1,218 \\
\hline & 6 & 1,463 \\
\hline & 8 & 1,817 \\
\hline & 10 & 1,922 \\
\hline & 12 & 2,125 \\
\hline & 14 & 0,973 \\
\hline
\end{tabular}

Tabel 6. Perhitungan Kultur Biomassa S.platensis dengan Pemberian Nutrisi yang berbeda dalam Skala Semi Outdoor.

\begin{tabular}{|c|c|c|}
\hline Nutrisi & $\begin{array}{c}\text { Hari } \\
\text { Penyamplingan }\end{array}$ & $\begin{array}{c}\text { Rata-Rata Kerapatan Biomassa } \\
(\mathrm{gr} / \mathrm{ml})\end{array}$ \\
\hline \multirow{5}{*}{0,00} & & \\
& 0 & 0,186 \\
& 2 & 0,253 \\
& 4 & 0,436 \\
& 6 & 0,543 \\
& 8 & 0,833 \\
& 10 & 1,169 \\
& 12 & 1,237 \\
& 14 & 0,651 \\
\hline \multirow{5}{*}{0,50} & 0 & 0,222 \\
& 2 & 0,357 \\
& 4 & 0,570 \\
& 6 & 0,635 \\
& 10 & 0,858 \\
& 12 & 1,261 \\
& 14 & 1,535 \\
& 0 & 0,745 \\
\hline \multirow{5}{*}{0,55} & 2 & 0,371 \\
& 4 & 0,563 \\
& 6 & 0,748 \\
& 8 & 1,105 \\
& 10 & 1,355 \\
& 12 & 1,529 \\
& 14 & 1,722 \\
& 0 & 0,827 \\
\hline \multirow{6}{*}{0} & 2 & 0,522 \\
& 4 & 0,823 \\
& 6 & 1,130 \\
& 8 & 1,347 \\
& 10 & 1,653 \\
& 12 & 1,826 \\
& 14 & 2,112 \\
& & 0,922 \\
\hline
\end{tabular}

Berdasarkan tabel diatas dapat dilihat bahwa untuk skala indoor dan semi outdoor jumlah kerapatan biomassa S.platensis paling tinggi pada pemberian nutrisi 0,60 $\mathrm{ml}$, nutirisi $0,55 \mathrm{ml}$, nutrisi $0,50 \mathrm{ml}$ dan paling rendah tanpa pemberian nutrisi. Jumlah kerapatan biomassa S.platensis 
yang paling tinggi pada skala indoor adalah sebanyak 2,112 $\mathrm{gr} / \mathrm{ml}$ untuk pemberian nutrisi $0,60 \mathrm{ml}$, pemberian nutrisi $0,55 \mathrm{ml}$ sebanyak $1,722 \mathrm{gr} / \mathrm{ml}$, pemberian nutrisi $0,50 \mathrm{ml}$ sebanyak $1,535 \mathrm{gr} / \mathrm{ml}$, dan tanpa pemberian nutrisi sebanyak $1,237 \mathrm{gr} / \mathrm{ml}$. Jumlah kerapatan biomassa S.platensis yang paling tinggi pada skala semi outdoor adalah sebanyak 2,125 $\mathrm{gr} / \mathrm{ml}$ untuk pemberian nutrisi $0,60 \mathrm{ml}$, pemberian nutrisi $0,55 \mathrm{ml}$ sebanyak $1,741 \mathrm{gr} / \mathrm{ml}$, pemberian nutrisi $0,50 \mathrm{ml}$ sebanyak 1,667 $\mathrm{gr} / \mathrm{ml}$, dan tanpa pemberian nutrisi sebanyak $1,426 \mathrm{gr} / \mathrm{ml}$.

Dalam hal ini jumlah kerapatan biomassa spirulina dengan pemberian dosis nutisi yang berbeda lebih tinggi pada skala semi outdoor dibandingkan pada skala indoor, hal ini dapat disebabkan oleh kondisi parameter kualitas air dan kondisi lingkungan pada skala semi outdoor lebih banyak mempengaruhi proses tingkat pertumbuhan biomassanya dibandingkan pada skala indoor, hal ini sesuia dengan Kawaroe et al., (2010), yang menyatakan bahwa komunitas mikroalga pada suatu perairan dipengaruhi oleh kondisi lingkungan antara lain temperatur (suhu), intensitas cahaya, derajat keasaman $(\mathrm{pH})$, aerasi(sumber $\mathrm{CO} 2$ ), dan salinitas.

Berdasarkan hasil uji Oneway Anova dari setiap perlakuan yang diberikan pada skala indoor dan semi outdoor terjadi perbedaan yang sangat nyata, karena memiliki nilai signifikan yang sama yaitu $\mathrm{p}<0,01$.Oleh sebab itu dilakukan uji lanjut LSD (Least Significance Diffrent) dapat dilihat pada Tabel 7 dan Tabel 8.
Tabel 7. Hasil Uji LSD Pertumbuhan Biomassa S.platensis dengan Pemberian Nutrisi yang berbeda dalam Skala Indoor.

\begin{tabular}{cccc}
\hline I (Nutrisi) & $\mathrm{J}$ (Nutrisi) & $\begin{array}{c}\text { Mean } \\
\text { Difference } \\
(\mathrm{I}-\mathrm{J})\end{array}$ & Signifikan \\
\hline \multirow{2}{*}{ Kontrol } & Nutrisi 2 & $-.364083^{* *}$ & .006 \\
& Nutrisi 3 & $.628583^{* *}$ & .000 \\
& & - & .000 \\
Nutrisi 1 & Nutrisi 3 & $.51925^{* *}$ &. \\
Keterangan: $* *$ & $\mathrm{p}<0,01$ (sangat berbeda nyata)
\end{tabular}

Tabel 8. Hasil Uji LSD Pertumbuhan Biomassa S.platensis dengan Pemberian Nutrisi yang berbeda dalam Skala Semi Outdoor.

\begin{tabular}{cccc}
\hline I (Nutrisi) & $\begin{array}{c}\mathrm{J} \\
(\text { Nutrisi) }\end{array}$ & $\begin{array}{c}\text { Mean } \\
\text { Difference } \\
(\mathrm{I}-\mathrm{J})\end{array}$ & Signifikan \\
& Nutrisi & - & \\
Kontrol & 2 & $.432833^{* *}$ & .002 \\
& Nutrisi & - & \\
& 3 & $.692167 * *$ & .000 \\
Nutrisi & - & \\
Nutrisi 1 & 3 & $.460875^{* *}$ & .001 \\
\hline Keterangan: $* *=\mathrm{p}<0,01$ (sangat berbeda nyata)
\end{tabular}

Dari hasil uji lanjut LSD Tabel 7 dapat dilihat bahwa pertumbuhan biomassa dengan pemberian dosis nutrisi yang berbeda pada skala indoor memiliki perbedaan yang sangat nyata yaitu antara kontrol dengan nutrisi 2 atau pemberian nutrisi sebanyak $0,55 \mathrm{ml}$ menunjukkan nilai p > 0,05 yaitu memiliki perbedaan yang nyata dan kontrol dengan nutrisi 3 atau pemberian nutrisi sebanyak $0,60 \mathrm{ml}$ menunjukkan nilai $\mathrm{p}<0,01$ yaitu memiliki perbedaan yang sangat nyata, sedangkan antara nutrisi 1 dan Nutrisi 3 menunjukkan nilai $\mathrm{p}<0,01$ yaitu memiliki perbedaan sangat nyata .

Pada Tabel 8 yaitu pertumbuhan biomassa dengan pemberian dosis nutrisi yang berbeda pada skala semi outdoor menunjukkan bahwa antara kontrol dengan nutrisi 2 atau pemberian nutrisi sebanyak $0,55 \mathrm{ml}$ dan antara nutrisi 1 dengan utrisi 3 sama-sama menunjukkan nilai $\mathrm{p}<0,05 \mathrm{ml}$ yaitu memiliki perbedaan yang nyata, sedangkan antara kontrol dengan nutrisi 3 memiliki nilai $\mathrm{p}<0,01$ yaitu memiliki perbedaan yang sangat nyata. 
Pertumbuhan biomassa S.platensis dapat dibandingkan antara skala indoor dan semi outdoor, yang mengalami peningkatan dari hari ke-0 sampai hari ke-12, setelah itu jumlah kerapatannya mengalami penurunan kembali pada hari ke-14, hal ini dapat dilihat dan dibandingkan jumlah kerapatan biomassanya antara Gambar 3 dan Gambar 4.

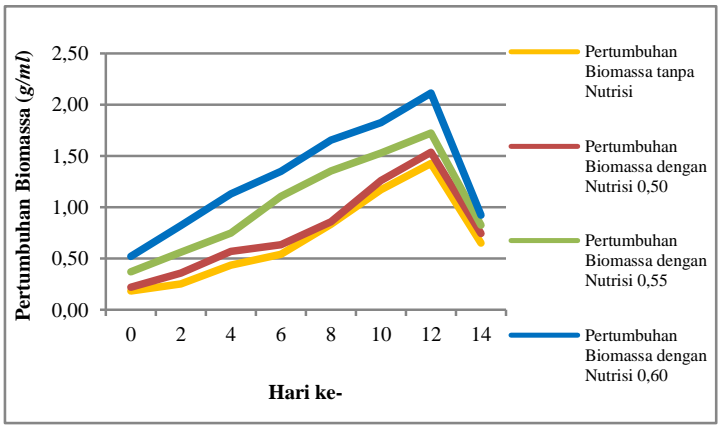

Gambar 3. Kerapatan Biomassa S.platensis pada Skala Indoor

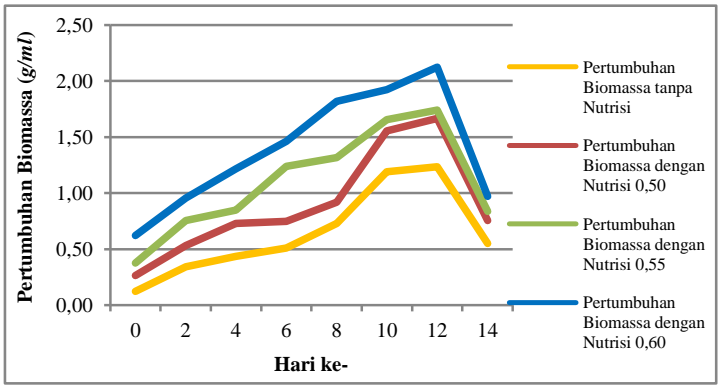

Gambar 4. Kerapatan Biomassa S.platensis pada Skala Outdoor

Dalam jumlah kerapatan biomassa S. platensis baik dalam skala indoor dan semi outdoor mengalami peningkatan dari hari ke-0 sampai hari ke 12 , kemudian mengalamani penurunan kembali pada hari ke-14. Dari hasil peningkatan ini, dapat dinyatakan bahwa dalam jumlah kerapatan biomassanya, $S$. platensis melewati beberapa fase, yaitu dari hari ke-0 sampai hari ke-4 mengalami fase lag, dari hari ke 5-12 mengalami fase eksponensial, dan hari ke 13-14 mengalami fase stasioner. Pemberian jenis nutrisi juga mempengaruhi jumlah kerapatan biomassa S.platensis. Dalam penelitian ini nutrisi yang digunakan adalah jenis Media Guillard atau F/2. Hal ini sesuai dengan yang dinyatakan oleh Jati et al., (2012) yaitu Media Guillard atau F/2 ini biasa digunakan untuk kultivasi mikroalga dan diketahui dapat menghasilkan jumlah kerapatan biomassa yang tinggi.

\section{Hasil Analisis Uji $\mathbf{T}$ Pertumbuhan Biomassa $S$. platensis dengan Pemberian Dosis Nutrisi yang berbeda pada Skala Indoor dan Semi Outdoor.}

Dari hasil analisis Uji $\mathrm{T}$ pada skala indoor didapatkan antara kontrol dengan dosis nutrisi $0,60 \mathrm{ml}$ memiliki perbedaan yang nyata, hal ini dapat dilihat dari hasil nilai signifikan yaitu 0,032 yang berarti $p$ $<0,05$. Hasil analisis Uji T pada skala semi outdoor juga menunjukkan antara kontrol dengan nutrisi $0,60 \mathrm{ml}$ memiliki perbedaan yang sangat nyata, hal ini juga dapat dilihat dari hasil nilai signifikan yaitu 0,007 yang berarti $p<0,01$ (Lampiran 8). Dari hasil analisis ini juga dapat dilihat bahwa pertumbuhan biomassa spirulina lebih mengalami peningkatan pada skala semi outdoor dibandingkan dengan skala semi outdoor.

\section{KESIMPULAN DAN SARAN}

\section{Kesimpulan}

Berdasarkan hasil penelitian terdapat pengaruh dalam pemberian dosis nutris media guillard, S.platensis mengalami peningkatan dengan pemberian nutrisi sebanyak $0,60 \mathrm{ml}$ baik itu skala indoor maupun semi outdoor, hal ini juga dapat dilihat dari hasil analisi Uji $\mathrm{T}$ yang didapatkan bahwa perbandingan antar kontrol dengan dosis nutrisi $0,60 \mathrm{ml}$ memiliki perbedaan yang sangat nyata yaitu 0,032 untuk skala indoor dan 0,07 untuk skala semi outdoor. Sedangkan untuk jumlah pertumbuhan biomassa $S$. platensis pada skala semi outdoor jumlah 
kerapatannya lebih tinggi dibandingkan dengan skala indoor.

\section{Saran}

Diharapkan pada penelitian selanjutnya dilakukan kultur Spirulina platensis dengan dosis nutrisi sebanyak

\section{DAFTAR PUSTAKA}

0,60 ml dan dilakukan dalam skala semi outdoor, serta dilakukan analisis terhadap faktor-faktor lain yang dapat mempengaruhi jumlah kerapatan biomassa $S$. platensis. Penelitian selanjutnya juga diharapkan dapat mengetahui dosis nutrisi yang lebih baik lagi untuk mempengaruhi pertumbuhan biomassa $S$. platensis tersebut.

1. Amini, S., dan R. Susilowati. 2010. Produksi biodiesel dari mikroalga Botryococcus braunii. Squalen. 5 (1).

2. BPPT, 2013, Development of Planning and Policy Support for Improving the Potential Production of Biogas as Renewable Energy in Indonesia's Tofu Industries, Renewable Energy-Efficiency Energy Partnership (REEEP) Environmental Technology Centre, The agency for the Assessment and Aplication of Technology.

3. Emzir. 2009. Metodologi Penelitian Pendidikan. Jakarta. Pt Raja Grafindo Persada.

4. Fikri. 2006. Kandungan Gizi Spirulina. http://www.kesehatan alami.com/sea cucumberspirulina-kandungan.php [20 Desember 2017].

5. Hariati, R. 2008. Pertumbuhan dan Biomassa Spirulina sp. dalam Skala Laboratorium. Jurnal Biologi. 10(1):19-22.

6. Isnansetyo, A., dan Kurniastuty. 1995. Teknik kultur phytoplankton dan zooplankton.Kanisius: Yogyakarta. hal. 34-85.

7. Jati, F., J. Hutabarat, dan V.E. Herawati. 2012. Pengaruh Penggunaan Dua Jenis Media Kultur Teknis yang Berbeda Terhadap Pola Pertumbuhan, Kandungan Protein, dan Asam Lemak Omega 3 EPA (Chaetoceros gracilis). Journal Of Aquaculture Management and Technology. 1.(1):221.235.

8. Kawaroe, M., T. Prartono, A. Sunuddin , S. W. Sari . 2010, Mikroalga: Potensi dan Pemanfaatannya Untuk Produksi Bio Bahan Bakar, PT. Penerbit IPB Press, Bogor.

9. Suryati. 2002. Pemanfaatan limbah cair pabrik gula (LCPG) untuk pertumbuhan Spirulina sp.. Skripsi. Fakultas Perikanan Universitas Brawijaya. Malang. 74 hal.

10. Tanjung, A. Rancangan Percobaan. 2014. Edisi Revisi (3). Penerbit Tantaramesta. Bandung : Assosiasi Direktorati Indonesia. 